\title{
JOURNAL.RU
}

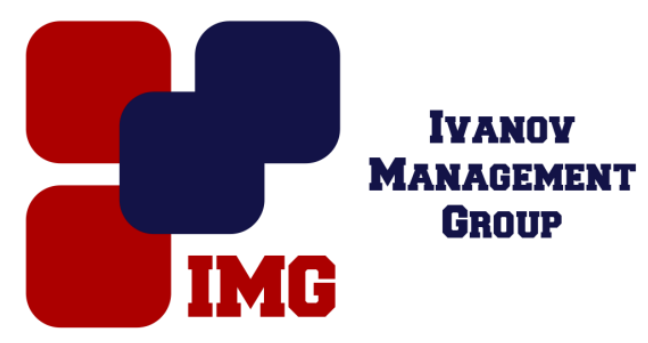

Халявкина М.A. Курский государственный университет Курск, Россия

doi: $10.18411 / 1 \mathrm{j}-31-05-2017-32$

idsp 000001:1j-31-05-2017-32

\section{Сформированность познавательных универсальных учебных действий у обучающихся профильных классов при изучении биологии}

\section{Аннотация}

В статье представлены результаты опытно-экспериментальной работы по формированию познавательных универсальных учебных действий на уроках биологии в профильных классах. Представлена динамика уровней сформированности познавательных действий. Проведен анализ результатов и их интерпретация.

Ключевые слова: УУД, познавательные УУД, коэффициент уровня сформированности умения.

Изучение состояния проблемы формирования познавательных универсальных учебных действий (УУД) при изучении биологии в психологопедагогической литературе показало, что не в полной мере обоснованы критерии отбора конкретных УУД в познавательный блок в процессе изучения биологии; недостаточно проработано методическое обеспечение (технологии, модели, средства развития УУД); не разработана единая система оценки, методики и инструментария мониторинга. Приходится констатировать, что формирование универсальных учебных действий на уроках биологии в старших классах - достаточно новое направление, требующее специального исследования, как в целом, так и в нашем регионе.

Опытно-экспериментальная работа осуществлялась в период 2015-2017 гг. на базе ОБОУ «Лицей-интернат № 1» г. Курска. Цель экспериментальной 
работы - проверка эффективности разработанных средств в формировании познавательных УУД на уроках биологии.

Констатирующий эксперимент (сентябрь-декабрь 2016) проводился для диагностики исходного уровня сформированности познавательных УУД у обучающихся старших классов на уроках биологии. Оценивали уровень развития следующих видов УУД: обобщение имеющихся знаний, установление причинно-следственной связи, анализ биологической информации с целью выделения признаков, поиск и выделение информации. Обработку результатов осуществляли по коэффициенту уровня сформированности умения (Ку) А.А. Кыверялга. При Ку> 0,7 умение сформировано на высоком уровне, при Ку = 0,50,7 - на среднем уровне, при Ку< 0,5 - материал усвоен не полностью (низкий уровень). Результаты начальной диагностики показаны в табл. 1.

Таблица 1.

Исходный уровень сформированности познавательных УУД по биологии

\begin{tabular}{|c|c|c|}
\hline Название познавательного действия & $\begin{array}{c}\text { Коэффициент } \\
\text { уровня } \\
\text { сформированности } \\
\text { умения }\left(\mathrm{K}_{\mathrm{y}}\right)\end{array}$ & Уровень сформированности \\
\hline Обобщение имеющихся знаний & 0,48 & Низкий \\
\hline Установление причинно-следственной связи & 0,45 & Низкий \\
\hline $\begin{array}{c}\text { Анализ биологической информации с целью } \\
\text { выделения признаков }\end{array}$ & 0,46 & Низкий \\
\hline Поиск и выделение информации & 0,47 & Низкий \\
\hline $\begin{array}{c}\text { Общий уровень сформированности } \\
\text { познавательных УУд }\end{array}$ & 0,46 & Низй \\
\hline
\end{tabular}

На формирующем этапе (январь-март 2017) была разработана и апробирована система заданий, способствующих эффективному формированию у обучающихся познавательных УУД. Обработку результатов, как и на констатирующем этапе, осуществляли по формуле А. А. Кыверялга. Обобщив результаты десяти уроков, рассчитали среднее значение коэффициента сформированности каждого из рассматриваемых действий (таблица 2).

Таблица 2.

Уровень сформированности познавательных УУД по биологии после апробащии комплекса разработанных заданий

\begin{tabular}{|l|c|c|}
\hline \multicolumn{1}{|c|}{ Название ПУуд } & $\begin{array}{c}\text { Коэффициент } \\
\text { уровня } \\
\text { сформированност } \\
\text { и умения }\left(К_{\mathrm{y}}\right)\end{array}$ & Уровень сформированности \\
\hline Обобщение имеющихся знаний & 0,68 & Средний \\
\hline Установление причинно-следственной связи & 0,67 & Средний \\
\hline $\begin{array}{l}\text { Анализ биологической информации с целью } \\
\text { выделения признаков }\end{array}$ & 0,69 & Средний \\
\hline Поиск и выделение информации & 0,70 & Высокий \\
\hline $\begin{array}{l}\text { Общий уровень сформированности } \\
\text { познавательных УУд }\end{array}$ & 0,68 & Средний \\
\hline
\end{tabular}


Сравнивая показатели Ку в начале эксперимента и после апробации заданий, по каждому из видов познавательных УУд мы наблюдаем увеличение его значения. Наибольший коэффициент сформированности оказался у умения поиска и выделения информации - Ку $=0,70$. Такой высокий показатель коэффициента можно объяснить не только особыми условиями, созданными для учащихся, но и особенностями биологического содержания, включающего в себя разнообразный материал.

После апробации разработанных заданий уровень сформированности познавательных универсальных учебных действий у обучающихся повысился, так как увеличился коэффициент уровня сформированности умения обобщения имеющихся знания на 0,2 , установления причинно-следственных связей на 0,22 , анализа биологической информации с целью выделения признаков и поиска (выделения) информации - на 0,23. Данные средства доказали свою эффективность в формировании познавательных УУД на уроках биологии.

Обобщенный показатель сформированности познавательных УУД в начале эксперимента был равен 0,46 , что соответствует низкому уровню сформированности познавательных УУД, после завершения эксперимента обобщенный показатель стал равен 0,68 , что соответствует среднему уровню сформированности познавательных УУД.

Таким образом, анализ полученных результатов позволяет сделать вывод об эффективности разработанных заданий и созданных педагогических условиях, обеспечивающих целенаправленное формирование познавательных универсальных учебных действий на уроках биологии.

Проведенная опытно-экспериментальная работа показала, что при целенаправленном применении системы тренировочных заданий при обучении биологии наблюдается положительная динамика в переходе сформированности у обучающихся познавательных универсальных учебных действий на более высокий уровень. 
1. Беспалько, В.П. Программированное обучение (дидактические основы) / В.П. Беспалько. - М.: Высш. шк., 1970. - 300 с.

2. Кыверялг, А.А. Методы исследования в профессиональной педагогике.- Таллин: «Валгус», 1980 г. - 334c.

3. Халявкина М.А. Психологические основы развития познавательных универсальных учебных действий старшеклассников в условиях профилизации основного общего образования // Современные тенденции развития науки и технологий. 2016. № 4-11. С. 133-135. 